\title{
An Analysis of Metaphor in Batak Toba Song Lyrics (Mother Love's Theme)
}

\author{
Doris Yolanda Saragih \\ Computer Technic, Politeknik Bisnis Indonesia, Indonesia \\ dorisyolandasaragih@gmail.com
}

\begin{abstract}
The aims of this research are to classify Metaphors in Batak Toba Song Lyrics (Mother's Love Theme).This research used Kovecse's theory (2010) said that there are three types of Metaphor: Structural Metaphors, Ontological Metaphors, and Orientational Metaphors. The method in this research applied qualitative method. The data were collected by downloading eight collection of Batak Toba Song Lyrics (Mother's Love Theme), listening them, transcribing them in English Language, identifying and putting them into table.The data were also analyzed by analyzing the data, classifying the data, deciding the research findings, and drawing the conclusion. The result in this research, there are 21 the data found in eight collection of Batak Toba Song Lyrics (Mother's Love Theme), namely 5 structural (23, 80\%), 10 ontological (47,61\%), and 6 orientational $(28,57 \%)$. Therefore, a number of selected Bataknese songs were dominated by ontological metaphor
\end{abstract}

Keywords

semantics, meaning, figurative meaning, metaphor, song

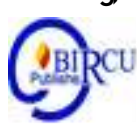

\section{Introduction}

Language is essentially a system of sound symbols, which is "arbitrary", or means" typically the sound of a word given no hint of its meaning" (Monaghan et al., 2014:1). Language was used by humans to communicate. Apart from being a means of communication, language also serves as a tool to express the soul, feelings, ideas, ideas and emotions of the human soul. To express the thoughts and feelings, generally the language can be divided into two types, they are spoken or written.

Maftuhah (2018:1) supported that spoken language is form of language that expressed directly using the spoken word orally, usually followed by tone and body language (Herman, Sibarani and Pardede, 2020). Spoken language can be found in the speech and conversation, while the written language is a form of language that uses the written text as a basic element. Written language can be found in the novel, newspaper, poem, magazine, song, etc. These two function are essentially an explanation of the speaker's knowledge of the meaning in a language.

Semantics was concerned with the study of how language organizes and expresses meaning as communicated by the speaker (or writer) and interpreted by the listener (or reader). As stated by Yule (2010:112) that semantics is related to the aspects of meaning in a language. In other words, meaning in semantics plays an important role in every speech act process, because without meaning, all utterance of a language is useless of the meaning (Thao and Herman, 2021).

As maintained by Saeed (2009:15), there are two types of meaning. They are literal meaning and non-literal meaning are traditionally called Figurative. Literal meaning is an original meaning of word, phrase, and sentences. Meanwhile figurative meaning is a departure from the ordinary form of expression in order to produce a greater effect or meaning. And in this research, the researcher focus discussed of figurative meaning based 
on the title of the research. Some authors used figurative language to produce images in readers minds and to express ideas in fresh, vivid, and imaginative ways. There are many types of figurative language such as: personification, simile, metaphor, hyperbola, irony, litotes, metanonym, and oxymoron. And one of its forms to correlation between semantic and figurative language; in this case, metaphor related to use of words, phrases, or sentences abstractly, not literally. In literary works, metaphors play an important role in communicated complex material and conveyed it more effectively to readers.

As far as we know, most existing research on metaphors only focused on literary works poetry, it is because metaphors are often identified with poetry. Metaphors are not only found in literary works such as poetry, short stories or novels, but in everyday human ideas metaphorical expressions are often used, for example in humor or comedy, even in song lyrics people often sing them. Song is one example of literature. Song as a piece of music with words that is sung has a function to express the thoughts and feelings. Song has two elements, such as lyric and music. Sinaga et al (2020:451) defined song lyric is essentially a language in its formulation which is not separated from the rules of music such as the rhythm, melody and harmony of the song (Thao and Herman, 2020). Most of the times, they carry the message (whatever that might be) with the purpose of motivating the listeners.

In this research, the researcher analyzed the types of metaphors that found out in Batak Toba's song lyrics (mother love's theme). Many of the Batak Toba songs have the theme of mother's love, therefore the researcher used the selection that aims to limit the amount of data, by considering certain criteria, there are eight songs chosen to be the object of research. These eight songs were chosen because they have meaningful and emotional lyrics about a mother's love for her child who is full of struggle and sacrifice for her child. The researcher interested in analyzing the meaning in a collection of Batak Toba song lyrics with the theme of a mother's love, because the lyrics have metaphorical meanings. The lyrics of this song consist of many types of metaphorical meanings that will be studied. And, the researchers selected eight songs that were already well-known and popular of many people. The songs chosen are songs that contain meaning to be learned.

Based on the phenomenon above, the researcher was interested to conduct a research entitle "An Analysis of Metaphor in Batak Toba Song Lyrics (Mother Love's Theme)". The researcher chosen this title because this research related to linguistics especially in semantics about metaphors and to help the reader to know about types of metaphors and the dominant type of metaphors in eight Batak Toba's Song Lyrics (Mother's Love Theme).

\section{Review of Literature}

\subsection{Semantics}

Language in its function as conveyed of the meaning, is closely related to semantic studies. Semantics is a branch of linguistics that studies the meaning of a language. The meaning referred to here is the meaning of language, either in the form of morphemes, words, or sentences. In correlation to this study, it is important to know the general description of semantics. Griffiths (2006:15) as cited Panjaitan et al (2020:10) defined semantic is the study of the sentence meaning coded in the overall sentence based on the elementary meaning of the sentence units. Futhermore, Yule (2006) in Maulana (2016:3) argued that "Semantics is the study of the meaning of words, phrases and sentences ". From this definition we can see that, the meaning under study belongs to the scope of linguistics. Beside semantics that focus on the internal meaning of words, phrases, or even 
sentences, Semantics explains the speaker's ability in understanding new words or sentences without any grammatical processes (Pakpahan et al, 2020)

According to another linguist, Griffiths (2006) as cited in Maftuhah (2018:14) stated that semantic is the study of the 'Toolkit' for meaning: knowledge encoded in the vocabulary of the language and its patterns for building more elaborate meaning, up to the level of the sentence meaning". It means that semanticis a science of developing a more detailed meaning based on the vocabulary structure of a language. Based on the opinion of the linguists above, the researcher concluded that semantics a branches of linguistic, which is studied, discussed, and explained about the meaning of words and sentences, as well as other elements that are symbolic by developed more detailed meanings based on the vocabulary structure of the language.

Sociolinguistics is an interdisciplinary science between sociology and linguistics, two fields of empirical science that have very close links, this science is applied in communicating with fellow humans. Collaborating in language, whether there are social activities or not in social activities (Darwis, 2018). Ridwan (2018) stated that The function of official language is usually dealing with certain business in a certain territory such as nation se court, parliament, and administration and it is not widely spoken in the society. However, it is possible that one language serves both functions.

\subsection{Meaning}

In our daily life we often heard and also used the word 'meaning', (which commonly synonymous with the word 'meaning') refer to meanings, concepts, ideas, ideas, and intentions that are manifested in the form of utterances, symbols or signs. The meaning in language utterances actually have same the meaning in the symbol system or other sign system because the real language also a symbol system. The only difference between them namely the meaning in language is manifested in symbols in the form of language units, there are words/lexemes, phrases, sentences, and so on.

Palmer (1981) as cited Akanya and Omachonu (2019:2) defined meaning as concept or ideas which can be transfer from the mind of the speaker to the mind of the bearer by embodying them as it were in the forms of language or another. On the report of Carston (2012:1) meaning is the concept meant or communicative intended by the speaker. Based on the statements, it can be concluded that meaning is a message conveyed by someone (source or sender) to another (observer or recipient) through words, sentences, and symbols in a context.

As maintained by Saeed (2009:15), there are two types of meaning. They are literal meaning and non-literal meaning as traditionally called Figurative. Literal meaning is an original meaning of word, phrase, and sentences. Meanwhile figurative meaning is a departure from the ordinary form of expression in order to produce a greater effect or meaning.

\subsection{Metaphor}

Etymologically, the concept of the word "metaphor" comes from the Greek, which is a combination of two words: "meta" which means transfer, and "pherein" which means to carry. So, the overall metaphor can be interpreted as a transfer or transfer. Basically, metaphor is a word or expression whose meaning is figurative and not literal because metaphor serves to explain a concept. Thus, the concept becomes easier to understand.

In literary works, metaphors play an important role in communicating complex material and conveying it more effectively to the reader.It is intended, so that the meaning conveyed by the author can be understood by the reader. In addition, metaphors can also 
help readers to capture accurate writers' insights, both physically and emotionally (Sitorus et al 2020: 13).

Many people found metaphors is difficult, especially in understanding their meaning. Danesi (2013:189), stated Metaphor explains how people conceptualize abstraction in concrete ways. In other words, metaphor can convert understanding from concrete or sensory to abstract or cognitive perception. Metaphor is a kind of figurative language which uses connotative meaning through the comparison without using the word 'like' or 'as' (Sitorus et al, 2020:13). This statement supported that metaphor related to the relationship between one word and another in forming a meaning. Metaphor means penetrating, that is, penetrating linguistic meaning. Metaphors are classified as figurative language (figure of speech), through the comparison without used the word comparison ('like' or 'as').

\subsection{Song}

As we know, song is a part of literature. According to Sitorus and Herman (2019), song is a one of the ways to communicate the enables human to cooperate. Song is considered to be a system of communication with other people using sounds and song to express a feeling, sense, idea, emotions or thought (p. 24). Song also is a combination of music and lyrics.

Dallin (1994) as cited Firdaus (2013:100) stated that, "Lyrics are written as a form of interaction between the writer and the listeners. Most of the times, they carry a message (whatever that might be) with the purpose of motivating the listeners. Lyrics in songs usually contain the author's experiences and ideas which are summarized in a certain theme, parsed and conveyed to the listener through language. Song lyrics are an expression of the author's feelings, thoughts and ideas which are realized in a special language. The special form of language in question is language that tends to be uncommon or commonly used in everyday life. Language in song lyrics is synonymous with beautiful and poetic language because in addition to express feelings or ideas by the songwriter, song lyrics are also intended to provide an entertaining effect.

Every song writer has his own freedom and way of choosing and arranging words according to his mood, imagination and linguistic knowledge. Therefore, the language in song lyrics is often as ambiguous as the language in poetry and tends to use figurative language. This research analyzed of the lyrics in the Bataknese Songs.

\section{Research Methods}

The research used qualitative as research design. Qualitative research is not only a set of techniques but also requires the efforts of an active researcher (Mason, 2002:113). The researcher applied descriptive qualitative research to find out the types of metaphor in the song lyrics of Batak Toba with the theme of mother's love, the researchers selected eight songs that have already well-known and popular of many people. The instrument of this research is the song lyrics of eight Batak Toba songs with theme of mother's love. There are Tangiang Ni Dainang (Mother's Pray) by Trio Elexis, Mauliate Ma Inang (Thank You Mother) by Trio Elexis, Dalan Na Rais (The Steep Path) by Trio Simenstar, Dainang (Mother) by Siantar Rap Foundation, Sabar Ho Inang (Be Patient, You Mother) by Margareth Siagian, Haholongi Inang Mi (Love Your Mother) by Style Voice, Patik Palimahon (The Fifth Commandment) by Trio Satahi, and Poda Mi Inang (Mother's Advice) by Jhon Kenedy Nadeak. 
In this research, researcher took data from Batak Toba song lyrics with the theme of mother's love found from the internet. Most of the Batak Toba's songs (theme of mother's love) have well-known in the songs contain metaphors meanings that require deep understanding of the song's lyrics. The researcher took eight song lyrics from Batak Toba songs with theme of mother's love. There are eight songs to analyzed, namely: (1) Tangiang Ni Dainang - Popularized by Viktor Hutabarat. (2) Mauliate Ma Inang Popularized by Trio Elexis. (3) Dalan Na Rais (Dainang) - Popularized by Trio Simenstar. (4) Dainang - Popularized by Siantar Rap Foundation. (5) Sabar Ho Inang - Popularized by Margareth Siagian. (6) Haholongi Inang Mi - Popularized by Style Voice. (7) Patik Palimahon - Popularized by Trio Satahi. (8) Poda Mi Inang - Popularized by Jhon Kenedy Nadeak.

As stated by Creswell (2014:192), the data collection steps include setting the boundaries for the studied, and collected information through unstructured or semi structured observations, interviews, and documents. After collected and selected, the data were analyzed. The data analysis in this research was conducted through follows:(1) Analyzing the song lyrics that contain types of metaphors meaning in the eight song lyrics.(2) Classifying the types of metaphors meaning in in the eight song lyrics. (3) Finding out the collected. (4) Generating tables to show the frequency of each types of metaphor in the eight song lyrics.

\section{Results and Discussion}

\subsection{Research Findings}

The data took from eight Batak Toba's song lyrics (mother love's theme) was analyzed into three types metaphors, they are: structural metaphors, ontological metaphors, and orientational metaphors.

\section{a. Types of Metaphors}

Types of Metaphors in Eight Collection Batak Toba's Song Lyrics (Mother Love's Theme). There are twenty one metaphors analyzed in this research. The types of Metaphors were Structural Metaphors, Ontological Metaphors, and Orientational Metaphors.

Table 1. The Percentage of the Types Metaphor Used Batak Toba Song (Mother Love's Theme)

\begin{tabular}{|c|l|c|c|}
\hline \multirow{2}{*}{ No. } & \multirow{2}{*}{ Types of Metaphor } & \multicolumn{2}{|c|}{$\begin{array}{c}\text { Eight Batak Toba's } \\
\text { Songs(Theme of Mother's Love). }\end{array}$} \\
\cline { 3 - 4 } & & Frequency & Percentage(\%) \\
\hline 1. & Structural & 5 & $23,80 \%$ \\
\hline 2. & Ontological & 10 & $47,61 \%$ \\
\hline 3. & Orientational & 6 & $28,57 \%$ \\
\hline \multicolumn{2}{|c|}{ TOTAL } & 21 & $100 \%$ \\
\hline
\end{tabular}

Table 1. showed the result of types metaphor used in Batak Toba's song lyrics. The frequency of types metaphor found in eight Batak Toba's songs (theme of mother's love). There are Tangiang Ni Dainang (Mother's Pray) by Trio Elexis, Mauliate Ma Inang (Thank You Mother) by Trio Elexis, Dalan Na Rais (The Steep Path) by Trio Simenstar, Dainang (Mother) by Siantar Rap Foundation, Sabar Ho Inang (Be Patient, You Mother) by Margareth Siagian, Haholongi Inang Mi (Love Your Mother) by Style Voice, Patik 
Palimahon (The Fifth Commandment) by Trio Satahi, and Poda Mi Inang (Mother's Advice) by Jhon Kenedy Nadeak. They consisted of structural metaphors $(23,80 \%)$, ontological metaphors $(47,61 \%)$, and orientation metaphors $(28,57 \%)$.

\section{b. The Most Dominant Type of Metaphors}

Based on the data, the researcher found that the type of ontological metaphor is often used in eight Batak Toba's song lyrics (mother's love theme), than the other two types of metaphors (structural and orientation). For more detailed finding, the researcher used the chart below:

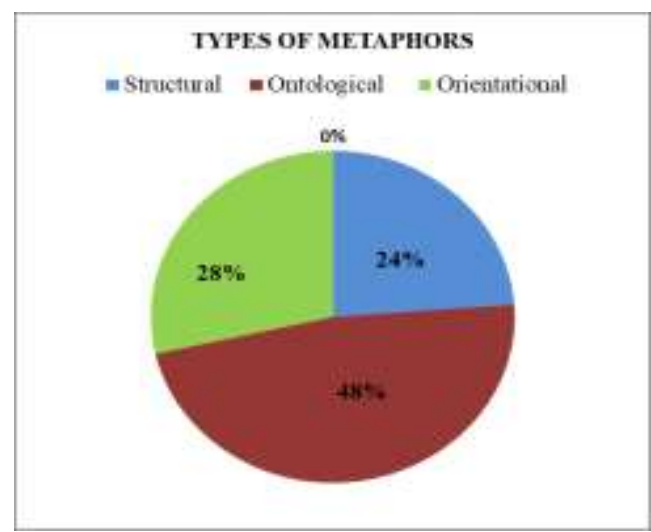

Figure 1. The Most Dominant Types of Metaphors

\subsection{Discussion}

This part discussed about the result of data analysis of Metaphor by using the theory that is proposed by Kovecses (2010). This part stated and clarified the types of metaphors and its meaning that used by song lyrics in eight Batak Toba's song lyrics (mother's love theme). After analyzing these song lyrics, the researcher found that there were 21 types of metaphors that were used in eight Batak Toba's song lyrics (mother's love theme),those were 5 structurals, 10 ontologies, and 6 orientations metaphor. Therefore, the researcher concluded that the most frequently used was ontological metaphor.

The first type, structural metaphor is found in Appendix II:\{S.1.St.12\}, \{S.3.St.12\}, $\{$ S.3.St.14\}, \{S.4.St.15\}, and \{S.7.St.10\}. In those lyrics, the song writer used another concept to express a concept.The second type, ontology metaphor is found in Appendix II: $\{$ S.1.St.1\}, \{S.2.St.12\}, \{S.2.St.15\}, \{S.3.St.4\}, \{S.3.St.15\}, \{S.4.St.27\}, \{S.4.St.28\}, \{S.6.St.19\}, \{S.8.St.12-13\},\{S.8.St.17-18\}. In those lyrics considers emotion, feeling, idea, and others as entities. The last type, orientation metaphor was found in Appendix II: $\{$ S.1.St.11\}, $\{$ S.1.St.15\}, $\{$ S.2.St.5\}, \{S.4.St.16\}, \{S.5.St.4 $\}$, and $\{$ S.7.St.3\}. Those lyrics were derived from our physical or cultural experiences involved up and down.

A reason the researcher want to discuss the types of metaphors, including because of a problem. The problem in question is the problem found by music listeners in understanding the meaning of song lyrics (figurative language), especially the types of metaphors, because generally music listeners do not really understand the meaning (figurative language) contained in song lyrics, especially in a collection of Batak Toba songs (mother's love theme).Metaphor is a process of transferring meaning that is used specifically to cause a certain effect, which is based on the similarity of function, form and use. Apart from song lyrics, we can also find metaphors in the dialogue in movies and also in our daily conversations. To determine the word is a type of metaphor, it is not only 
according to three types in this research. There are many theories that can be used to determine the used of metaphors.

This research has several differences with previous studies. In research conducted by Deru Lukmana, Rusdi Noor Rosa, and Leni Marlina (2019) entitled "An Analysis of Metaphor in the Lyrics of Selected Minangkabaunese Songs". This research focused on analyzing metaphors in Minangkabau songs. The purpose of this research was to determine the different types of metaphors in a collection of Minangkabau songs (theme fail in love/romance and song theme rantau) using the theory of Lakoff and Johnson (1980). This research uses descriptive qualitative research design. The data were taken from Minangkabaunese songs based on failing in love/romance themes and rantau themes. The results of this study were 23 data found in the Minangkabau song with failing in love/romance themes: structural $(34.78 \%)$, orientation $(39.13 \%)$, ontological $(26.09 \%)$. And 25 data were found in the Minangkabaun song with rantau themes: structural (56\%), orientational(36\%), ontological $(8 \%)$.

There are several similarities and differences between previous studies and this research. First, the similarities of the two studies are both using descriptive qualitative research as the research design. While the difference from previous research with this research is the object, the object of this research is Batak Toba's song lyrics (mother's love theme), while the previous research object was Minangkabaunese song lyrics based on failing in love/romance themes and rantau themes. The second difference is that this research (Kovecses, 2010) and previous research (Lakoff and Johnson, 1980) used a different theory. However, although using a different theory, the theoretical context is the same.

\section{Conclusion}

Based this research on analysis the meaning of metaphor in the collection of Batak Toba song lyrics (mother love's theme), the researcher concluded that the lyrics of Batak Toba song can be examined the meaning of metaphor by using Kovecses theory. In this theory, three types of metaphors are explained, including structural metaphors, ontological metaphors, and orientational metaphors. And in this study, the researcher found that there were 21 data from eight songs studied. There are 5 structural metaphors $(23.80 \%), 10$ ontology metaphors $(47.61 \%)$, and 6 orientation metaphors $(28.57 \%)$. So that, the most dominant type of metaphor is the ontology metaphor because it has the most amount of data, which is ten of total data.

One form of figurative language, that widely known is metaphor. Metaphor is a language that used specifically to cause certain effects, through a process of transferring meaning based on the same function, and form. The use of metaphors is quite rarely understood by some people, especially among millennial children today. Especially on regional pop songs. Therefore, the researcher analyzed the types of metaphors in Batak Toba Songs (Mother's Love Theme). 


\section{References}

Akanya, J and Omachonu, C. G. (2019). Meaning and Semantic Roles of Words in Context. International Journal of English Language and Linguistics Research. Vol. 7(2): pp 1-9.

Carston, R. (2012).Word Meaning and Concept Expressed. De Gruyter Mouton. Vol. 29(4): pp 607-623

Creswell, J. (2014). Research Design: Qualitative, Quantitative, and Mixed Methods Approaches (4th ed.). California: SAGE Publications.

Danesi, M. (2013). Encyclopedia of Media and Communication. Toronto: University of Toronto Press.

Darwis, M. (2018). Politeness Language Analysis in Teenagers Reviewed from Sociolinguistics. Budapest International Research and Critics in Linguistics and Education (BirLE) Journal. P. 15-22.

Firdaus, E. A. (2013). Textual Meaning in Song Lyrics. (Published) Thesis. Bandung: Universitas Pendidikan Indonesia.

Herman, Sibarani, J. K., and Pardede, H. (2020). The Effect of Jigsaw Technique in Reading Comprehension on Recount Text. Cetta: Jurnal Ilmu Pendidikan, Jayapangus Press ISSN 2615-0891 (E) Vol. 3 No. 1 (2020), PP. 84-102. Retrieved from http://jayapanguspress.penerbit.org/index.php/cetta/article/view/413

Kovecses, Z. (2010). Metaphor: A Practical Introduction, Second Edition. New York: Oxford University Press.

Lukmana, D. Rosa, R N and Marlina, L. (2019). An Analysis of Metaphor in the Lyrics of Selected Minangkabaunese Songs. E-Journal of English Language \& Literature.Vol. 8(3): pp 202-211.

Maftuhah, E. R, (2018). Figurative Language in Selected Brian Macknight's Songs. (Master's Thesis). Makassar: Faculty of Cultural and Sciences of Hasanuddin University.

Mason, J. (2002). Qualitative Researching, 2nd Edition. London: Sage Publications.

Maulana, R. (2016). A Semantic Analysis of Metaphor Found in Selected Lyrics of "The Script", "Katy Perry", and "Michael Bublé. (Unpublished) Thesis. Jawa Tengah: Universitas Muhammadiyah Surakarta.

Monaghan P et al,. (2014). How arbitrary is language?.Phil. Trans. R. Soc. B369: 20130299. http://dx.doi.org/10.1098/rstb.2013.0299.

Pakpahan, D. P., Herman., Purba, C. N., and Purba, R., (2020). An Analysis of Connotative Meaning on Westlife Song Lyrics Based on Semantics. American Journal of Humanities and Social Sciences Research (AJHSSR), Volume 04 - Issue 10, PP. 34-44

Panjaitan, P. S. A., Herman., and Sinaga, Y. K. (2020). Figurative Language Analysis t Song Lyrics Of Billie Eilish "When We All Fall Asleep, Where Do We Go?” Album. American Journal of Humanities and Social Sciences Research (AJHSSR), Volume 04 - Issue 10, PP. 10-20

Ridwan, M. (2018). National and Official Language: The Long Journey of Indonesian Language. Budapest International Research and Critics Institute-Journal (BIRCIJournal). P. 72-78.

Saeed, J. I. (2009). Semantic. United Kingdom: Blackell Publishers Ltd.

Sinaga, D., Herman., and Marpaung, T. I. (2020). Deixis in the Song Lyrics of Lewis Capaldi's "Breach" Album. JOLLT Journal of Languages and Language Teaching, 
P-ISSN: 2338-0810, Vol 8, No 4 (2020), E-ISSN: 2621-1378, PP. 450-457. Retrieved from http://ojs.ikipmataram.ac.id/index.php/jollt/article/view/2843

Sitorus, E. and Herman. (2019). A Deixis Analysis of Song Lyrics in Calum Scott You Are the Reason. International Journal of Science and Qualitative Analysis.Vol. 5(1): pp 24-28.

Sitorus, R., Herman, Silalahi, D.E., and Sihombing, P. S. R. (2020). An Analysis Language Metaphor Found in "Twilight" Novel. Global Science Independent Journal, Vol 1 No 1 (2020), PP. 10-21. Retrieved from: https://syniutajournals.com/index.php/GSIJ/article/view/166

Thao, N. V. and Herman. (2020). An Analysis of Deixis to Song Lyrics "My Heart Will Go on" by Celine Dion. Communication and Linguistics Studies. Vol. 6, No. 2, 2020, pp. 23-26. Retrieved from http://www.sciencepublishinggroup.com/journal/paperinfo?journalid=357\&doi=10.1 1648/j.cls.20200602.12

Thao, N. V. \& Herman. (2021). An Analysis of Idiomatic Expressions Found in Ed Sheeran's Selected Lyrics Songs. CENTRAL ASIAN JOURNAL OF LITERATURE, PHILOSOPHY AND CULTURE, 2(1), 12-18. Retrieved from http://cajlpc.centralasianstudies.org/index.php/CAJLPC/article/view/54 